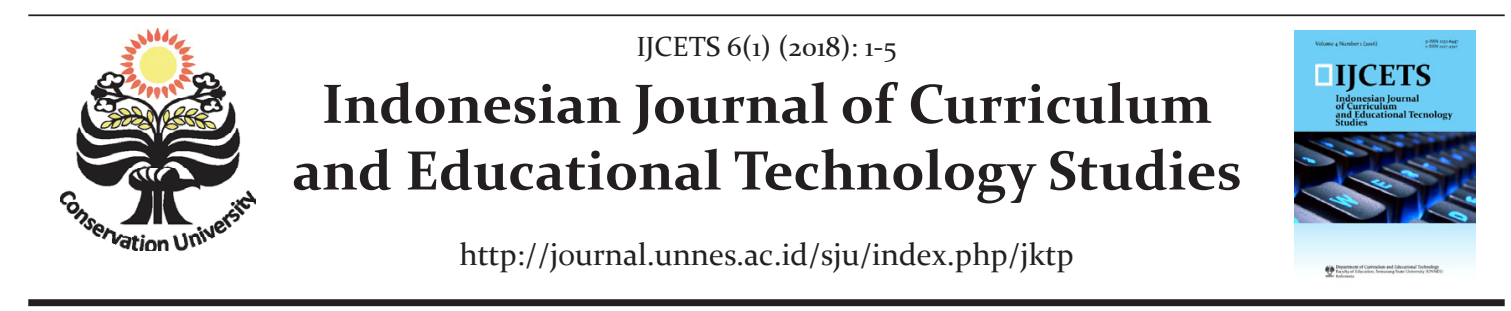

\title{
The Role of Social Media on Students GPA
}

\author{
Karzan Wakil, ${ }^{1,2}{\text { Rebwar Nasraddin, }{ }^{3} \text { Rajab Abdulrahan }}^{3}$ \\ 'University of Human Development, Kurdistan, Iraq \\ ${ }^{2}$ Sulaimani Polytechnic University, Kurdistan, Iraq \\ Institute of Training and Educational Development, Sulaimani, Iraq
}

DOI: http://dx.doi.org/10.15294/ijcets.v3i1.8675

\section{Article History \\ Received : February 2018 Accepted : March 2018 Published : April 2018}

\section{Keywords}

Facebook; educational technology; social media; GPA

\begin{abstract}
Abstrak
Dalam dunia pendidikan media sosial merupakan perangkat pendidikan yang dapat menarik perhatian siswa baik di dalam maupun di luar kelas dan memengaruhi kesuksesan mereka. Salah satunya wujudnya adalah penggunaan media sosial yang berlebihan dan membuahkan masalah-masalah sosial serta berimbas pada prestasi akademik mereka. Dalam penelitian ini peneliti melakukan survei di beberapa sekolah dasar di daerah Sulaimaniyah berkaitan dengan efek penggunaan media sosial, terutama Facebook, terhadap capaian akademik siswa. Balikan survei yang diterima oleh peneliti sejumlah 127 dokumen dan hasil analisis menunjukkan bahwa penggunaan media sosial berimbas negatif pada prestasi siswa. Rinciannya, siswa yang menggunakan Facebook lebih dari tiga jam rata-rata prestasinya $66,88 \%$, untuk penggunaan antara satu hingga tiga jam rata-rata prestasinya $73,59 \%$, dan untuk penggunaan di bawah satu jam rata-rata prestasinya $82,93 \%$. Secara keseluruhan tiap penggunaan Facebook selama satu jam rata-rata prestasi siswa menurun 5,35\%, oleh karena itu dapat disimpulkan bahwa pengurangan durasi penggunaan Facebook dapat membantu meningkatkan skor ratarata prestasi siswa.
\end{abstract}

\begin{abstract}
In academia, social media is an educational tool that can attract students inside and outside classrooms and affect their total success. Using social media can have negative effects on the students like wasting time and social problems which have negative effects on grades and studying performance. In this work, conducted a survey in a basic school at Sulaymaniyah Governorate about the impact of using social media on students, Facebook particularly. We received 127 forms; then our analysis shows that using social media has a negative impact on students' grades. Students who use Facebook for more than three hours had average grades of (66.88\%), (73.59\%) for one to three hours, and (\%82.93) for less than an hour usage. Overall, every one hour using Facebook, the average score decreases by (\%5.35). Therefore, decreasing the duration of using Facebook is helpful to increase the student's average grades.
\end{abstract}




\section{INTRODUCTION}

Since the introduction of social media, the way of communication between people, collaborate, interact, and sharing contents are changed. Social media is starting to be an important platform knowledge sharing, communications not on the personal level only, also for organizations. This tendency created an interesting area for researchers, professionals, and academics to conduct researches about different aspects of social media (Ahmed, Ahmad, Ahmad, \& Zakaria, 2018).

Nowadays, the global attention towards social media is increasing which is due to the popularity and social impact. The rapid growth of the form of media revolutionized the ways of knowledge sharing, collaborate, and communicate with each other (Filo, Lock, \& Karg, 2015). This kind of media platform includes an extensive range of different media such as social networking (i.e. Facebook), microblogs (i.e. personal blogs), video and picture sharing (i.e. YouTube and Flickr), and cooperative websites such as Wikipedia.

These media platforms are established and prominent for individuals to create channels for sharing knowledge and looking for people with similar thought and sharing knowledge with them. Social media changed the way we interact, learn, live and work. They allow for easy access to the required knowledge in the cyberspace (Ahmed et al., 2018).

Using social media by students can facilitate access to required information as quickly as possible. Using online platform (i.e. school website) can provide students with information about schools, rules, regulations, and announcements. Previous observations showed that students could dig their required information faster and more efficient. If it used wisely, students can have several advantages which allow them to become better organized in term of school affairs (i.e. schedule and regulations), facilitate learning online, access to information, expanding knowledge, and building relationship (Cruz, 2017).

However, when it is overused, social media can backfire on the student and reduce the grades. The reason is that social content in social media is causing students to spend more time on social media platform, reading stories, chatting with family and friends and accessing other social content. It leads to lack of listening in the class and waste time. Also, social media may cause a student to be distracted and unable to focus on studying, because they are always in possession of their smart gadgets which allow them to access social content online anytime they want. Thus, the overall studying performance is degraded (Santosh, 2017).

There are several previous works in the area of impacts of social media on various parts of society. Kaewktipong, Chen, \& Ratcham (2016) for example tried to examine the factors which can allow students' satisfaction to be increased to enhance Information System (IS) field trips by using social media. Then, examine their determination to continue using social media in future. They showed that in order for the students to have increased satisfaction, course-in-structure should guarantee that students realize that social media used for improving field trip study to be easy, accepted by their peers, and dependable.

On the other hand, Alwagait, Shahzad, \& Alim (2015) surveyed to find the affections which are caused by using social media in universities in Saudi Arabia. They explored the usage of social media and the factors which affects the studying performance negatively. The results showed that a linear relation between GPA score and using social media in a week does not exist. The students featured that alongside with using social media, time management is also a factor that influences students' degraded performance.

Pempek, Yermolayeva, \& Calvert (2009) conducted an experiment using 92 undergraduate students. They asked them to fill a diary for each day in one week by reporting the period that they used to access the Facebook website. When the week is finished, they also completed a survey. The outcome of the experiment showed that students are using Facebook for 30 minutes in average to check the web content, not posting contents. They use Facebook to communicate on one-to-many style, in which they are creating content and publicize it to their friends. They were spending more time checking other's content rather than posting on Facebook. They revealed that Facebook is often used for social interaction with other students whom they had relationship previously outside social media. In addition, they showed that identity makers of areas like religion, politics, working, and young adults utilized social media to show their identity.

In previous works, we found the effective technology in teaching and learning in the pri- 
Karzan Wakil et al./Indonesian Journal of Curriculum and Educational Technology Studies 6(1) (2018): 1-5

mary and high schools. In the ones we present how enriching classroom by using new technology (Wakil, Qaisar, \& Mohammed, 2017), the result of this research presented that the learning increased $22.9 \%$ after using technology for teaching inside classrooms. In another work, we found the side effect of electronic games on the students GPA (Wakil, Omer, \& Omer, 2017) when using games helps students to think if they use it under control, but they decreased their GPA when used $1-3$ hours per day by $-2.41 \%$.

We also explained how ICT subject has a positive role in the Primary schools (Wakil, Muhamad, Sardar, \& Jalal, 2017), we found that schools whose their student studied ICT subject has evolved and increased their teaching process compared with other schools. Moreover, we found the effective Microlearning in the process of learning (Mohammed, Wakil, \& Nawroly, 2018) this learning is a new style of learning and memorizing information in students mind for long times.

With increasing the types of social media and social contents on the internet, increasing the learning performance and efficiency by students is important. Therefore, finding the impact of using social media on studying performance is crucial. In this paper, we conducted an experimented to find how social media affects the students' studying performance in a basic school at Sulaymaniyah Governorate. We provided a questionnaire to ask for several aspects of using social media and the impact of using it on their overall study.

\section{METHOD}

The methodology of this work is planned with the intention to get precise results out of work. We had a social environment that we performed our questionnaire which is several basic schools at Sulaymaniyah Governorate. The students we chose were from both genders and given the questionnaire form which was about the subject of our work. Then, we gave the forms to students in each of the schools, clarifying the content of the forms. This paper mainly focuses on quantitative and numeric data.

The steps of our works are illustrated in figure 1. After gathering questionnaire forms, we sorted, organized them, and analyzed them using Microsoft Excel 2010 to draw results from our survey.

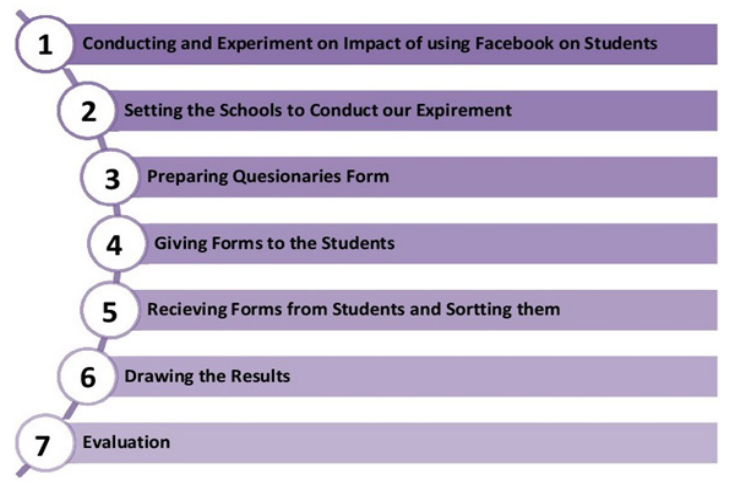

Figure 1 Steps of research process

\section{RESULT AND DISCUSSION}

In order to implement the questionnaire, 200 questionnaire forms are given to students in both genders and from different schools. We asked about many aspects of using Facebook and how to use it for studying. When we received back the forms, 30 of them were empty, which leaves 170 forms usable. Then we discarded another 43 forms, because they didn't have any Facebook account or not visiting their account every day. Meaning that many students are using Facebook as a daily manner.

We asked about using Facebook for studying, or other things (i.e., entertainment, playing online games, checking news, and so on). We received $29.9 \%$ of students claiming that they use Facebook for studying and checking knowledge content. However, $70.1 \%$ mentioned that they use Facebook for other purposes than studying. Figure 2 shows a pie chart which illustrates the purpose of using Facebook by students.

\section{Using Facebook for Learning}

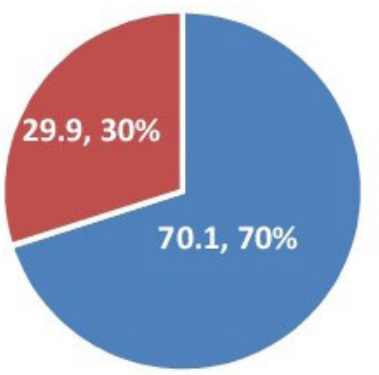

Figure 2 shows the purpose of using Facebook

Another question was about using Facebook for managing the school's affairs and studying. We asked about four different aspects of using Facebook which are exchanging studying 


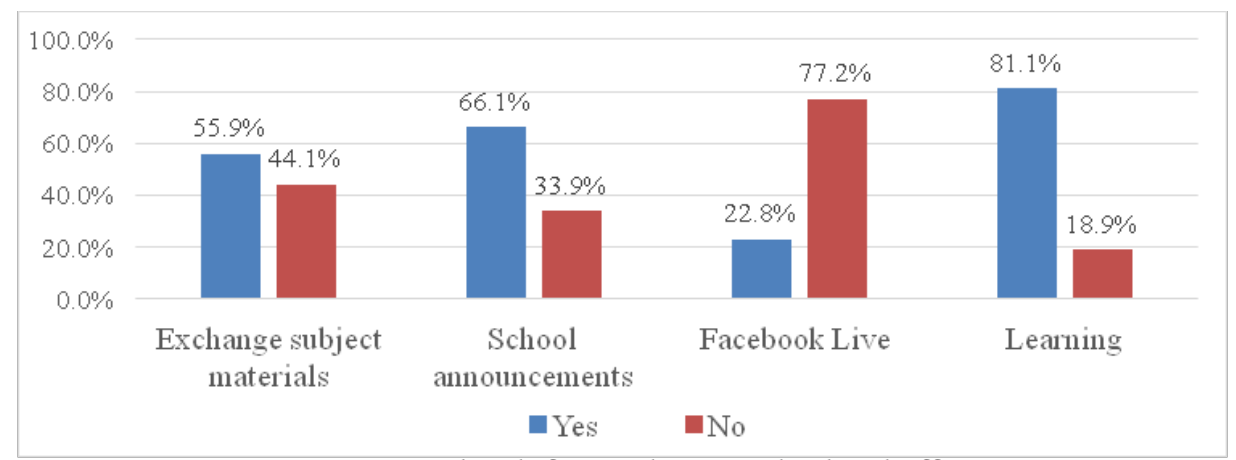

Figure 3 Using Facebook for studying and school affairs

materials, school announcements, using "Facebook Live" feature, and using Facebook for learning. We asked about using Facebook to exchange ideas and subjects for a specific class. $55 \cdot 9 \%$ of them mentioned that they use Facebook for exchanging the subject's materials (doing homework, performing tasks which are given by teachers and so on).

However, 44.1\% mentioned that they don't use Facebook for anything related to school subjects as shown in figure 3 (First two column from the left side). The second column from left shows using Facebook for knowing about school announcements. $66.1 \%$ of students pointed out that they use Facebook for knowing about school announcement. On the other hand, 33.9\% pointed that they don't use Facebook in such way. After launching Facebook Live, Facebook opened the opportunity to be used better way, especially for students.

Facebook Live allows students to have sharing session and they get to benefit from it. When we asked the student about the possibility of using Facebook Live during their studies, only $\mathbf{2 2 . 8 \%}$ indicated that they use Facebook Live during studying. While $77.2 \%$ mentioned, they do not use Facebook Live to study. Figure 3 shows using Facebook Live feature for studying (Third columns from left).

One of the important reasons which made us conduct this experiment was to find the relation between period usage of Facebook by students and their school grades. We put the questionnaire forms into three groups. Group A uses Facebook for less than 1 hour; Group B uses Facebook for from 1 hour to 2 hours, Group $C$ uses Facebook for more than 2 hours. Then we asked their school management to give us the GPA of the students to see how using Facebook affects their grades. As Table 1 indicates, the student's group who use Facebook for shorter periods, showed that they have better grades on avera- ge. However, the students who use Facebook for longer periods, have shown to get lower grades on average. Table 1 relates students' grades to the periods they spent on Facebook.

Table 1 Using periods and GPA

\begin{tabular}{lll}
\hline Groups & Usage Periods & Average GPA \\
\hline Group A & Less than 1 hour & $82.93 \%$ \\
Group B & $\mathbf{1 - 2}$ hours & $73.59 \%$ \\
Group C & $\begin{array}{l}\text { More than } 2 \\
\text { hours }\end{array}$ \\
Difference between Group & $\mathbf{1 6 . 0 5 \%} \%$ \\
A and C \\
$\begin{array}{l}\text { Decreasing grades per one } \\
\text { hour of using Facebook }\end{array}$ \\
\hline
\end{tabular}

We found that the difference between the GPA of group A and C is $16.05 \%$. If we divide this outcome on the number of groups that we had, we can indicate the average decreasing amount of GPA per one hour of using Facebook. It means if the students use Facebook for an extra hour on a daily basis, the GPA will be decreased by $5.35 \%$ on average. Figure 4 indicates the reduction in students grades when they use Facebook for longer periods.

As the outcome from figure 4 shows, excessive usage of using Facebook caused students to give less attention to their lectures. The reason is that checking any social content requires the user to check that content for longer periods to track any updates on that content (i.e. Likes, comments, and so on) and responding to that content. The duration of these activities increases when the Facebook user puts a new social content (i.e. check-in, photo, video, and so on) (Ahmed et al., 2018). Therefore, using social media for longer periods increases the student's distraction and lack of time management. Thus, using Facebook has a negative impact on learning performance, and it decreases the GPA of the students. 
Karzan Wakil et al./Indonesian Journal of Curriculum and Educational Technology Studies 6(1) (2018): 1-5

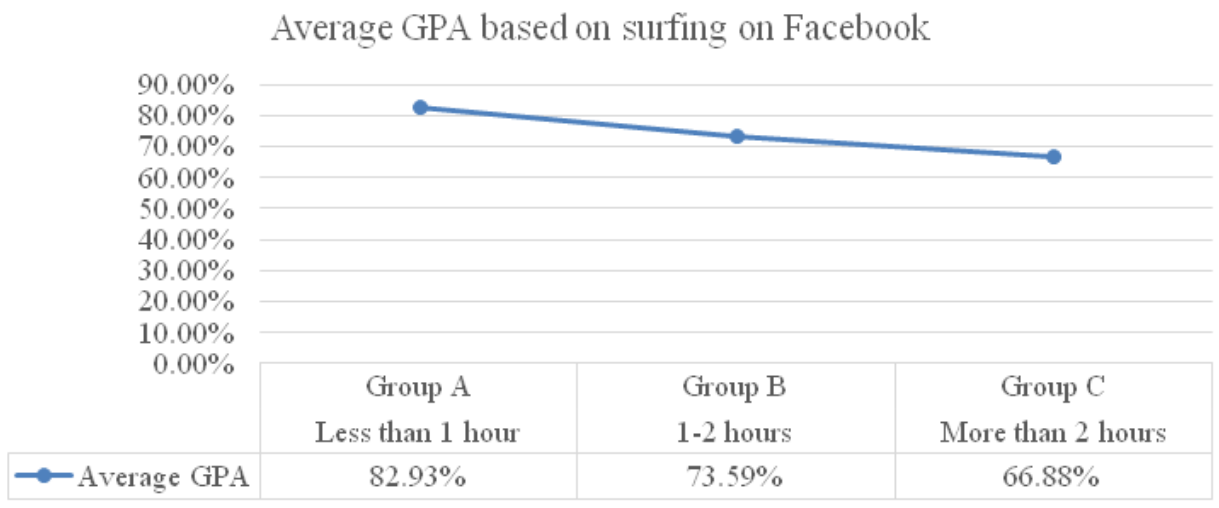

Figure 4 Correlation between the period of using Facebook and student grades

\section{CONCLUSION}

Positively using social media can be very useful for improving student's knowledge, and making learning efficient. In this work, we showed some criteria that students want to use Facebook for school affairs and other things related to studying. However, overusing, may backfire, reduce the student's potential and studying performance. Our work indicated that majority of students are using Facebook for purposes other than studying and learning. Moreover, we showed that student GPA is reduced if the student spends longer periods on Facebook. Our analysis indicates that for each 1 hour of using Facebook, the student GPA increase by a factor of $5.35 \%$. The reason is that when student spends a long period on social media, they will lose focus on their studies and get distracted.

\section{REFERENCES}

Ahmed, Y. A., Ahmad, M. N., Ahmad, N., \& Zakaria, N. H. (2018). Social media for knowledge-sharing: A systematic literature review. Telematics and Informatics. doi: https://doi.org/10.1016/j. tele. 2018.01.015

Alwagait, E., Shahzad, B., \& Alim, S. (2015). Impact of social media usage on students academic performance in Saudi Arabia. Computers in $\mathrm{Hu}$ man Behavior, 51, 1092-1097.

Cruz, A. M. D. L. (2017). Positive and Negative Use of Social Media by Students. Retrieved from BlogDash: http://blog.blogdash.com/mediaindustry/positive-negative-use-social-mediastudents/
Filo, K., Lock, D., \& Karg, A. (2015). Sport and social media research: A review. Sport management review, 18(2), 166-181.

Kaewkitipong, L., Chen, C. C., \& Ractham, P. (2016). Using social media to enrich information systems field trip experiences: Students' satisfaction and continuance intentions. Computers in Human Behavior, 63, 256-263.

Mohammed, G. S., Wakil, K., \& Nawroly, S. S. (2018). The Effectiveness of Microlearning to Improve Students' Learning Ability. International Journal of Educational Research Review, 3(3), 32-38.

Pempek, T. A., Yermolayeva, Y. A., \& Calvert, S. L. (2009). College students' social networking experiences on Facebook. Journal of applied developmental psychology, 30(3), 227-238.

Santosh, H. (2017). 6 Positive And 4 Negative Effects Of Social Media On Children. Retrieved from Mom Junction: http://www.momjunction. com/articles/negative-effects-of-social-media-on-children_o0353633/\#gref

Wakil, K., Muhamad, D., Sardar, K., \& Jalal, S. (2017). The Impact of Teaching ICT for Developing Education Systems. International Journal of Advanced Research (IJAR), 5(7), 873-879. doi:10.21474/IJARo1/4793

Wakil, K., Omer, S., \& Omer, B. (2017). Impact of Computer Games on Students GPA. European Journal of Education Studies. doi:10.5281/zenodo.827400

Wakil, K., Qaisar, N., \& Mohammed, C. (2017). Enriching Classrooms with Technology in the Basic Schools. European Journal of Open Education and E-learning Studies. doi:10.5281/zenodo.841925 